Article

\title{
Achieving Sustainability in the Construction Supervision Process
}

\author{
Svetlana Mjakuškina, Maija Kavosa and Inga Lapina * \\ Institute for Quality Engineering at the Faculty of Engineering Economics and Management, Riga Technical \\ University, Riga LV-1048, Latvia \\ * Correspondence: inga.lapina@rtu.lv; Tel.: +371-67-089-498
}

Received: 1 July 2019; Accepted: 23 July 2019; Published: 25 July 2019

\begin{abstract}
In recent years, the construction industry faced major challenges in ensuring a balance between environmental, economic, and social aspects. There are a lot of different studies on different aspects of the construction industry. Most of the available studies look at the construction supervision process mainly from the constructor's point of view. However, there is little research on the market surveillance and supervision process performed by the government and its role in ensuring sustainability in a particular area. The aim of this study was to identify the main activities within the construction supervision process to achieve the sustainability of construction. The theoretical framework of the concept of sustainability in construction and in the activities of the supervision process was analyzed on the basis of a literature survey. The research revealed a connection between sustainability elements and the construction supervision activities. The results of the survey identified the most important factors that influence, negatively as well as positively, the achievements of sustainability in the supervision process. The research results are significant in order to create a construction supervision process which would not only ensure the compliance with the set requirements but also help achieve sustainability in the particular area. Research Limitations/Implications: Research is focused on the supervision process of public building construction in Latvia.
\end{abstract}

Keywords: construction; construction supervision; control; sustainability; safety

\section{Introduction}

In recent years, the statistics show the growing impact of the industry on the development of the national economy. In Latvia, for example, in 2018, the construction industry contributed $7.1 \%$ of Latvia's gross domestic product [1]. Compared to 2017, the construction output growth in 2018 showed the development of the construction sector assets which, according to calendar-adjusted data at constant prices, increased by $21.9 \%$ [2]. The construction industry not only influences the economy, but also has a direct influence on the social aspects of life, by creating, modifying, and improving the living environment. At the same time, the construction industry has a significant impact on the environment throughout the whole life cycle of a building, starting with the mining of raw materials until the end of life of the building, i.e., its demolition [3]. Between 2003 and 2011, the European Union (EU27) consumed 1.200-1.800 million tons of construction materials per annum for new buildings and refurbishment. A lot of raw materials (65\% of total aggregates, i.e., sand, gravel, and crushed rock) are used to produce construction materials [4]. In the EU27, approximately 850 million tons of construction and demolition waste is generated per annum [5]. In recent years, the construction industry faced major challenges in ensuring a balance between environmental, social, and economic aspects, and the manner in which the construction process is realized [6]. It is now critical to seek new approaches and apply creative and innovative solutions to the improvement of the construction process to be competitive 
and sustainable on the marketplace [7]. Many authors focused their attention on the different aspects of the construction industry. Some authors emphasized the role of digitalization, automatization, and use of new technologies in the construction process, which is becoming an integral part of the construction operations. These technologies, as well as open data, provide additional support for the decision-making processes in the frame of unconventional and sudden events [8]. Some authors emphasized the role of entrepreneurs in developing new approaches, taking innovative and original actions [9-11]. Realization of an open innovation strategy was used to adopt new ideas or technologies in the construction companies in order to ensure sustainable development [5]; the strategy and the tactics of the government play a significant role in achieving the main principles of sustainability [12]. The conventional framework of open innovation refers to corporate willingness to learn from the outside, but is less often about the extent to which a corporation shares its knowledge with outsiders [13]. As knowledge-based urbanization proceeds, the size of a knowledge city increases [14]. There are a lot of different studies on different aspects of the construction industry. Most of the available studies looked at the construction supervision process mainly from the constructor's point of view. However, there is little research on the market surveillance and supervision process performed by the government and its role in ensuring sustainability in particular area.

The role of the construction supervision process is to ensure public safety through proactive identification of non-compliances at the construction sites. In 2017, during the control supervision of public building construction, various types of non-compliance were determined in $37 \%$ of cases. In order to ensure the quality and safety of the construction operations, the role of supervision considerably increased [15]. Supervision of the construction process should ensure that the objective of sustainable development is taken into account in all phases of construction in order to protect the interests of present and future society [16]. There are different objects and elements of sustainability in different phases of the construction process [17] that should be evaluated during the supervision process in order to translate the principles of sustainable development to the construction process [18].

The research focuses on sustainability principles in the construction supervision process. The aim of this study was to identify the main activities within the construction supervision process to achieve the sustainability of construction. The theoretical framework of the concept of sustainability in construction and in the activities of the supervision process was analyzed on the basis of a literature survey. The evaluation and analysis of the role of supervision in the construction field provided a general notion of the supervision process as a strategically important activity in helping to ensure public safety and protect the interests of society by proactively determining non-compliances at the construction sites. The research revealed a connection between sustainability elements and the construction supervision activities. The authors introduce the notation and outline the main information based on the results of the empirical study of the supervision process in Latvia, and present the results of the survey analysis in order to offer their conclusions.

\section{Research Design}

In the first step, the authors performed a comprehensive literature review to identify activities within the construction supervision process, and interactions with the key elements of sustainable construction, as well as its impact on the ability to achieve sustainability in the construction supervision process.

In order to provide qualitative content analysis of the literature review for determining and defining the main principles of sustainable construction and the activities of the construction supervision process, the following questions were asked:

1. "What are the main elements of sustainable construction?"

2. "What activities does the construction supervision process include?" 
The research consisted of several steps. The first step was to determine sources for study selection. The digitalized libraries were chosen bearing in mind that this is a commonly used source of academic articles. The libraries used were Science Direct, SCOPUS, Web of Science, and EBSCOhost.

The following keywords were used to select studies in the previously identified digital libraries: "sustainable construction", "sustainability AND construction", "construction supervision", and "construction AND supervision". The inclusion criteria were determined as studies written in English, and studies published in scientific journals. The exclusion criterion was if the title or abstract provided evidence indicating the irrelevance of the study to the area of research. In the research results, studies published since 1996 were selected. As a result of the multi-step article selection process, 29 key articles were identified.

After the literature review, the second step was to perform the survey. The survey questionnaire was designed so as to collect data on the main factors that influence the achievement of sustainability in the supervision process from the constructor's perspective, thereby assessing the performance of sustainable construction supervision. The population of the survey was all construction specialists that were certified in the construction area at the time of the survey-8362. The survey was performed from April to July 2018, and 673 specialists provided their responses.

This paper proceeds as follows: Section 3 provides qualitative content analysis of the literature review for determining and defining the main principles of sustainable construction and activities of the construction supervision process; Section 3 also includes comparative analysis for getting an insight into the relationships between the main sustainability principles and the activities of the construction supervision process; Section 4 presents quantitative and qualitative analysis of the survey results of the main factors that have an impact on the achievement of sustainable construction supervision; Section 5 offers the authors' conclusions.

\section{Literature Review}

\subsection{Sustainability in the Construction Industry}

The first definition of sustainability was provided by the World Commission on Environment and Development as "development that meets the needs of the present without compromising the ability of future generations to meet their own needs" [19]. The concept of sustainability generates awareness of the production and use of the resources in different processes, like residential, commercial, or recreational [20]. Through the literature review, the authors found that, currently, there is no common definition of sustainability due to the fact that a significant number of existing research papers analyze various aspects of sustainable construction. Authors of the articles consistently identified three main pillars of sustainable construction - environmental, economic, and social [3,21-23]. The development of the construction industry in the present world is unimaginable without digitalization, automatization, and the use of new technologies. Taking this into account, combining with the analysis of the articles as stated earlier, in the contest of the construction supervision process, the authors identified that sustainable construction in the contemporary world consists of four pillars, with the fourth being technological [24-27]. The technological aspects of sustainable construction include research and development $(R \& D)$ of new materials and technologies which improve energy efficiency, use raw materials, and encourage green construction, embracing new technologies in building regulations. $R \& D$ and innovation, which earlier in the 1990s were confined to mainly adaptive technologies, are now moving into the realm of a creative and open innovation mode [28]. The main pillars of sustainable construction are illustrated in Figure 1. In order to achieve sustainable construction, activities should integrate all four elements. 


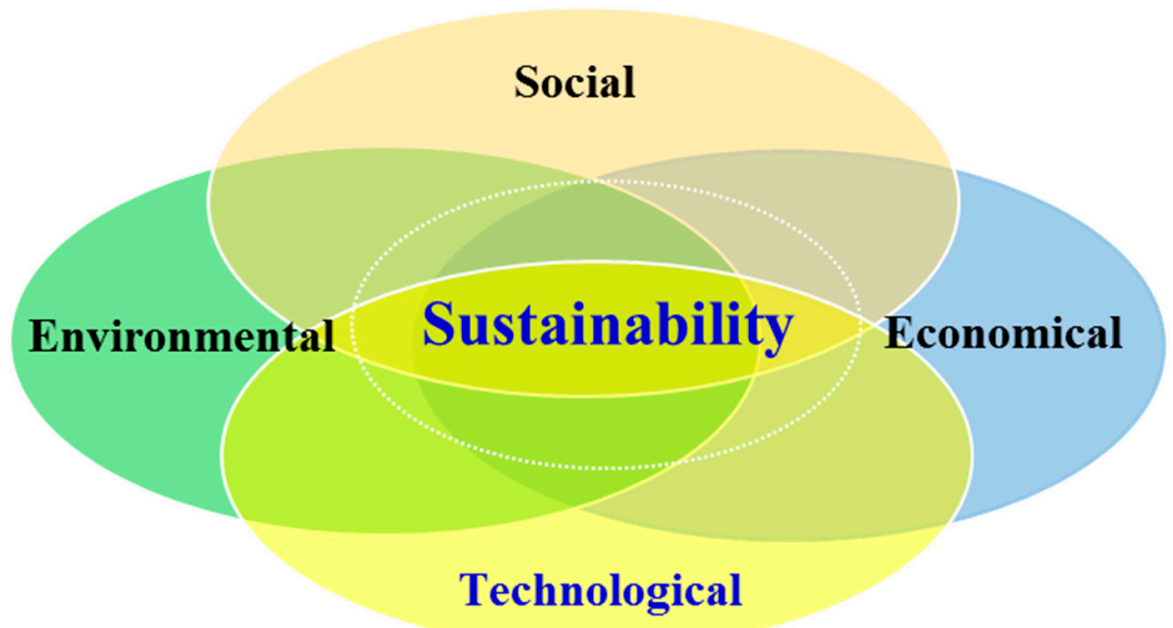

Figure 1. The main pillars of sustainable construction (created by the authors).

The activities of sustainability cover the whole life cycle of a building, starting with the mining of raw materials and reduction of the consumption of raw materials during the manufacturing of construction products until the end of life of the building (i.e., its demolition), minimizing construction and demolition waste and ensuring appropriate waste disposal and recycling processes [3,29-33]. The construction process itself involves a lot of different activities that influence sustainability, such as use of energy-efficient equipment, effective use of resources, minimization of construction waste, implementation of innovative technologies, involvement of multiple stakeholders, and raising knowledge and awareness of the aspects of sustainable construction [3,31-35]. In order to reach sustainable construction, it is necessary to have a close cooperation and common understanding of the principles of sustainable construction among the participants of the construction process [35]. The activities performed by the participants of the construction process should ensure compliance with a set of requirements and regulations. According to the legislation, the supervision of construction activities should be performed to support the implementation of sustainable construction practices.

In order to identify the main activities of the construction supervision process, a literature review was performed.

\subsection{Activities within the Construction Supervision Process}

The construction supervision process is not regulated by any binding documents; thus, there are various approaches to perform it. In order to ensure the quality and safety of the construction operations, the role of supervision increased considerably [15].

Through the literature review, the authors identified various activities within the construction supervision process: compliance supervision, quality control, sampling, measuring safety performance, observation, rule management, fault detection and mitigation as a proactive intervention, site data collection, progress monitoring and modeling, communication, coaching, report generation, support for new solutions, and technologies.

Many authors pointed out the role of communication between the persons involved in the construction process and the supervisor, not only to inform about the non-compliances found and to ensure corrective actions, but also to prevent possible non-compliances by proactive intervention [36-44]. Such activities include an on-board meeting prior to supervision activities, as well as coaching of the construction process participants. Effective communication results in the improvement of personnel behavior and an increased level of safety and compliance at the construction site [45].

The development of a platform for piloting new areas or developing new technologies is emphasized by Hienonen et al. [37]; construction supervision also includes monitoring the progress 
of activities at the construction site, modeling possible situations based on the site data collection to proactively identify possible risks and non-compliances [37,38,40,45-48].

Activities within the construction supervision process should ensure and help achieve sustainable construction. In order to identify the relationship between the main elements or pillars of sustainable construction and supervision activities, the authors posed the following question: "What type of actions and activities influence the main elements of sustainability?"

Based on the results described above, the relationships between the main sustainability principles and the activities of the construction supervision process were identified; they are shown in Table 1.

Table 1. The activities of the construction supervision process.

\begin{tabular}{|c|c|c|c|c|c|}
\hline Key References & $\begin{array}{c}\text { Activities of } \\
\text { Construction } \\
\text { Supervision Process }\end{array}$ & Environmental & Economical & Technological & Social \\
\hline $\begin{array}{l}\text { Laitinen et al. [36], Kines et al. [45], } \\
\text { Choudhry [38], Han et al. [40]. }\end{array}$ & Observation & $\mathrm{x}$ & & & $\mathrm{x}$ \\
\hline Laitinen et al. [36], Kines et al. [45]. & Feedback, coaching & & & & $\mathrm{x}$ \\
\hline $\begin{array}{l}\text { Montmain et al. [49], Laitinen et al. [36], } \\
\text { Hardison et al. [41]. }\end{array}$ & Fault detection & $\mathrm{x}$ & & & \\
\hline $\begin{array}{l}\text { Kines et al. [45], Hardison et al. [41], } \\
\text { Wang et al. [48]. }\end{array}$ & $\begin{array}{c}\text { Proactive } \\
\text { intervention }\end{array}$ & $\mathrm{x}$ & $x$ & & \\
\hline Hegazy et al. [37], Choudhry [38]. & Site data collection & $\mathrm{x}$ & & $\mathrm{x}$ & \\
\hline $\begin{array}{l}\text { Hegazy et al. [37], Sanz [46], } \\
\text { Hienonen [39], Wang et al. [48]. }\end{array}$ & Quality control & $\mathrm{x}$ & & & \\
\hline Hegazy et al. [37]. & Report generation & & & & $\mathrm{x}$ \\
\hline Choudhry [38] & $\begin{array}{l}\text { Measuring safety } \\
\text { performance }\end{array}$ & $\mathrm{x}$ & & & \\
\hline
\end{tabular}

Based on the analysis of the survey results, it can be concluded that construction supervision activities have a connection with and influence the achievement of elements of sustainable construction. Most of the activities, approximately $70 \%$ of the construction supervision process, influence the environmental principle of sustainable construction. At the same time, the activities that involve the use of new technologies influence the technological principles. The survey identified that most of the activities have influence on more than one sustainable construction pillar. The role of supervision in ensuring the quality and safety of construction operations increased considerably [15].

In 2018, Latvia's construction industry accounted for 7.1\% of its gross domestic product (GDP), contributing 1,817,971 euros. In 2018, compared to 2017, the construction output growth showed that the development of construction sector assets, according to calendar-adjusted data at constant prices, increased by $21.9 \%$. According to the building information database, there are 5904 construction 
merchants in Latvia. More than 208,000 are employed in the industry, including 8362 certified specialists [51,52].

In Latvia, construction supervision is ensured by the building authorities of municipalities and one state institution-the State Construction Control Bureau.

The competences among municipalities and the State Construction Control Bureau are divided and defined in the Construction Law. The supervision of construction work is performed by the building inspectors. According to the building inspector register in the building information system, there are 279 construction inspectors in Latvia as of 2019 [53]. The responsibilities of inspectors are defined in the Construction Law. The inspectors should examine and confirm the compliance of construction with the preidentified building requirements and design. They are also required to ensure that the construction process is properly supervised by the assigned party to monitor that the execution of work, materials, and technologies used meet the compliance requirement [54].

\section{Applying a Survey of Constructors in Analyzing the Sustainable Construction Supervision Process}

In order to accurately execute an evaluation of the existing construction supervision process performed by building inspectors in Latvia, it is necessary to identify factors that influence the achievement of sustainability in the supervision process from the constructor's perspective, thereby assessing the performance of sustainable construction supervision.

The population of the survey was all construction specialists that were certified in the construction area at the time of the survey-8362. The sample size at the $95 \%$ validity level was calculated in accordance with the accepted best practice. As per the error selection accepted in research practice, the representative error in the survey was 5\% [55]. Until May 2018, 673 construction specialists certified by eight certification bodies of constructors took part in the survey. The representativeness of the research was ensured. The first part of the survey was published in 2018 [56].

Evaluation of How Sustainable Construction Supervision is Assessed-The Survey Results

In assessing the sustainable construction supervision process performed by the supervision authorities, the authors decided that, in addition to the theoretical analysis of the research area, it was necessary to focus the subsequent survey on identifying the main factors influencing the supervision process performed by the supervision authority from the constructor's perspective, i.e., revealing which activities promote sustainable construction supervision and which should be further improved in the process.

The first part of the survey provides general information about the respondents. In total, $47.4 \%$ of the respondents are certified by the Latvian Association of the Civil Engineers, 17\% by the Latvian Association of Heat, Gas, and Water Technology Engineers, 14.3\% by the Latvian Association of Energy Constructors. Furthermore, $52.8 \%$ of the respondents are between 30 and 50 years old, $40.7 \%$ of the respondents are 50 and more years of age, and $6.5 \%$ are less than 30 years of age. Additionally, $76.7 \%$ of respondents have education equal to the sixth level of the European Qualifications Framework (EQF) in the European Higher Education Area.

The second part of the survey provides information about the respondents' view on the performed supervision process. The main activities that should be further improved by the supervision authority in the process of the construction supervision are outlined in Table 2.

Based on the results, the authors can conclude that most of the respondents cited "bureaucracy", "ambiguous interpretation of regulations", "lack of qualified professionals", and "lack of clearly defined control criteria" as the most important factors negatively influencing the supervision process performed by the supervision authority toward the achievement of sustainability. 
Table 2. The most frequent impact factors influencing negatively the achievement of sustainability in the supervision process.

\begin{tabular}{clcc}
\hline No & \multicolumn{1}{c}{ Impact Factor } & Frequency (\%) of all Respondents & Order \\
\hline 1. & Bureaucracy & 26 & 1 \\
2. & Ambiguous interpretation of regulations & 12 & 2 \\
3. & Lack of qualified professionals & 11 & 3 \\
4. & Lack of clearly defined control criteria & 10 & 4 \\
5. & Formal approach & 9 & 5 \\
6. & Not using new technologies & 8 & 6 \\
7. & Corruption & 8 & 7 \\
8. & Lack of methodical materials & 6 & 8 \\
9. & Lack of united order in the performance of procedures & 5 & 9 \\
10. & Lack of collaboration with the parties involved & 5 & 10 \\
\hline
\end{tabular}

The results of the survey on factors that, according to the respondents, have a positive impact on the tendency to reach sustainability in the construction process are outlined in Table 3.

Table 3. The most frequent impact factors influencing positively the achievement of sustainability in the supervision process.

\begin{tabular}{clcc}
\hline No & \multicolumn{1}{c}{ Impact Factor } & Frequency (\%) of All Respondents & Order \\
\hline 1. & Professional competence of specialists & 19 & 1 \\
2. & Collaboration with the parties involved & 17 & 2 \\
3. & Using new technologies & 15 & 3 \\
4. & Internal control system & 13 & 4 \\
5. & Availability of consultations of specialists & 11 & 5 \\
6. & Communication & 9 & 6 \\
7. & Public availability of information & 9 & 7 \\
8. & Clearly defined activities in the case of unconformity & 7 & 8 \\
\hline
\end{tabular}

When summarizing the answers of the respondents, it can be noted that most of the respondents cited the "professional competence of specialists", "collaboration with the parties involved", "using new technologies", and "internal control system" as the most important impact factors positively influencing the achievement of sustainability in the performed supervision activities.

Upon summarizing the received survey data, the authors conclude that the main impact factors which received the highest rating from Latvian certified construction specialists and which negatively influence the achievement of sustainability in the construction supervision process are associated with the organization of the supervision process itself, i.e., bureaucracy, ambiguous interpretation of regulations, lack of qualified professionals, and lack of clearly defined control criteria. Consequently, the main impact factors that received the highest rating and contribute to the achievement of sustainability in construction supervision process are related to the professional competence of specialists, collaboration with the parties involved, using new technologies, and an internal control system.

\section{Conclusions}

Following an in-depth analysis of the survey, the authors propose a new approach to the elements of sustainable construction, supplementing the existing elements of social, economic, and environmental with a fourth element- technological. Thus, sustainable construction consists of four pillars-environmental, economic, social, and technological. The activities of sustainability cover the whole life cycle of a building starting with the mining of raw materials until the end of life of the building. 
The construction process involves a variety of activities that influence sustainability, such as use of energy-efficient equipment, effective use of resources, minimization of construction waste, implementation of innovative technologies, involvement of multiple stakeholders, and raising knowledge and awareness of sustainable construction aspects. According to the legislation, supervision of construction activities should be performed in a way that ensures support of the implementation of sustainable construction practices. Through the literature review, the authors identified various activities within the construction supervision process: compliance supervision, quality control, sampling, measuring safety performance, observation, rule management, fault detection and mitigation for proactive intervention, site data collection, progress monitoring and modeling, communication, coaching, report generation, support for new solutions, and technologies.

All the identified construction supervision activities have a correlation with the key principles of sustainability. This allows concluding that the supervision process has a direct influence on the achievement of sustainable construction.

The results of the survey identified the most important factors that influence, negatively as well as positively, the achievements of sustainability in the supervision process from the constructor's perspective: "bureaucracy", "ambiguous interpretation of regulations", "lack of qualified professionals", and "lack of clearly defined control criteria" are the main factors negatively influencing the supervision process. Furthermore, the main impact factors that contribute to the achievement of sustainable construction supervision are related to the "professional competence of specialists", "collaboration with the parties involved", "using new technologies", and "internal control system", which also have a high importance and a positive impact on ensuring high-quality construction work in order to meet the requirements of sustainable construction supervision.

The research results are significant in order to create a construction supervision process that would not only ensure the compliance with the set requirements, but also help achieve sustainability in the particular area.

The authors conclude that further in-depth studies should be performed on the identified factors in order to develop a construction supervision process based on the measured and evaluated factors.

Author Contributions: Conceptualization, S.M.; methodology, S.M.; writing—original draft, S.M.; formal analysis, M.K.; project administration, M.K.; supervision, I.L.; writing-review and editing, I.L.

Funding: This research received no external funding.

Acknowledgments: The research questionnaire was developed by the group of PhD students of the Riga Technical University. The research was done with support from the State Construction Control Bureau of Latvia.

Conflicts of Interest: The authors declare no conflict of interest.

\section{References}

1. Gross Domestic Product and Gross Value Added. Available online: https://www.csb.gov.lv/lv/statistika/s tatistikas-temas/ekonomika/ikp/galvenie-raditaji/iekszemes-kopprodukts-un-kopeja-pievienota-vertiba (accessed on 30 April 2019).

2. Construction Output Increased by $21.9 \%$ in 2018. Available online: https://www.csb.gov.lv/lv/statistika/stati stikas-temas/buvnieciba-rupnieciba-tirdznieciba/buvnieciba/meklet-tema/2593-buvnieciba-un-izsniegtas (accessed on 30 April 2019).

3. Yılmaz, M.; Bakış, A. Sustainability in construction sector. Procedia Soc. Behav. Sci. 2015, 195, $2253-2262$. [CrossRef]

4. European Commission. Resource Efficiency in the Building Sector. Available online: http://ec.europa.eu /environment/eussd/pdf/Resource\%20efficiency\%20in\%20the\%20building\%20sector.pdf (accessed on 30 April 2019).

5. Yun, J.J.; Won, D.; Park, K. Dynamics from open innovation to evolutionary change. J. Open Innov. Technol. Mark. Complex. 2016, 2, 7. [CrossRef]

6. Wibowo, M.A.; Elizar; Sholeh, M.N.; Adji, H.S. Supply chain management strategy for recycled materials to support sustainable construction. Procedia Eng. 2017, 171, 185-190. [CrossRef] 
7. Roša, A.; Lāce, N. The open innovation model of coaching interaction in organizations for sustainable performance within the life cycle. Sustainability 2018, 10, 1-17.

8. Inkinen, T.; Helminen, R.; Saarikoski, J. Port Digitalization with open data: Challenges, opportunities, and integrations. J. Open Innov. Technol. Mark. Complex. 2019, 5, 30. [CrossRef]

9. Wagener, S.; Gorgievski, M.; Rijsdijk, S. Businessman or host? Individual differences between entrepreneurs and small business owners in the hospitality industry. Serv. Ind. J. 2010, 30, 1513-1527. [CrossRef]

10. Zampetakis, L.A.; Vekini, M.; Moustakis, V. Entrepreneurial orientation, access to financial resources, and product performance in the Greek commercial TV industry. Serv. Ind. J. 2011, 31, 897-910. [CrossRef]

11. Lim, S.; Ribeiro, D.; Lee, S.M. Factors affecting the performance of entrepreneurial service firms. Serv. Ind. J. 2008, 28, 1003-1013. [CrossRef]

12. Cooke, P. Green governance and green clusters: Regional \& national policies for the climate change challenge of Central \& Eastern Europe. J. Open Innov. Technol. Mark. Complex. 2015, 1, 1.

13. Gupta, A.; Dey, A.; Singh, G. Connecting corporations and communities: Towards a theory of social inclusive open innovation. J. Open Innov. Technol. Mark. Complex. 2017, 3, 17. [CrossRef]

14. Yun, J.J.; Jeong, E.; Yang, J. Open innovation of knowledge cities. J. Open Innov. Technol. Mark. Complex. 2015, 1, 343. [CrossRef]

15. Ma, Z.; Cai, S.; Mao, N.; Yang, Q.; Feng, J.; Wang, P. Construction quality management based on a collaborative system using BIM and indoor positioning. Autom. Constr. 2018, 92, 35-45. [CrossRef]

16. Bajjou, M.S.; Chafi, A.; Ennadi, A.; El Hammoumi, M. The practical relationships between lean construction tools and sustainable development: A literature review. J. Eng. Sci. Technol. Rev. 2017, 10, 170-177. [CrossRef]

17. Abdellatif, M.; Al-Shamma, A. Review of sustainability in buildings. Sustain. Cities Soc. 2015, 14, 171-177. [CrossRef]

18. Bavafa, A.; Mahdiyar, A.; Marsono, A.K. Identifying and assessing the critical factors for effective implementation of safety programs in construction projects. Saf. Sci. 2018, 106, 47-56. [CrossRef]

19. Brundtland, G.H. Report of the World Commission on Environment and Development: "Our Common Future"; United Nations: New York, NY, USA, 1987.

20. Trindade, E.P.; Hinnig, M.P.F.; Da Costa, E.M.; Marques, J.S.; Bastos, R.C.; Yigitcanlar, T. Sustainable development of smart cities: A systematic review of the literature. J. Open Innov. Technol. Mark. Complex. 2017, 3, 11. [CrossRef]

21. Park, J.; Yoon, J.; Kim, K.-H. Critical Review of the Material Criteria of Building Sustainability Assessment Tools. Sustainability 2017, 9, 186. [CrossRef]

22. Li, H.; Zhang, X.; Ng, S.T.; Skitmore, M. Quantifying stakeholder influence in decision/evaluations relating to sustainable construction in China-A Delphi approach. J. Clean. Prod. 2018, 173, 160-170. [CrossRef]

23. Yu, T.; Shi, Q.; Zuo, J.; Chen, R. Critical factors for implementing sustainable construction practice in HOPSCA projects: A case study in China. Sustain. Cities Soc. 2018, 37, 93-103. [CrossRef]

24. Mousa, A. A Business approach for transformation to sustainable construction: An implementation on a developing country. Resour. Conserv. Recycl. 2015, 101, 9-19. [CrossRef]

25. Ingrao, C.; Messineo, A.; Beltramo, R.; Yigitcanlar, T.; Ioppolo, G. How can life cycle thinking support sustainability of buildings? Investigating life cycle assessment applications for energy efficiency and environmental performance. J. Clean. Prod. 2018, 201, 556-569. [CrossRef]

26. Shan, M.; Hwang, B.G.; Zhu, L. A Global Review of Sustainable Construction Project Financing: Policies, Practices, and Research Efforts. Sustainability 2017, 9, 2347. [CrossRef]

27. Darko, A.; Chan, A.P. Critical analysis of green building research trend in construction journals. Habitat Int. 2016, 57, 53-63. [CrossRef]

28. Patra, S.K.; Krishna, V.V. Globalization of R\&D and open innovation: Linkages of foreign R\&D centers in India. J. Open Innov. Technol. Mark. Complex. 2015, 1, 7.

29. Murtagh, N.; Roberts, A.; Hind, R. The relationship between motivations of architectural designers and environmentally sustainable construction design. Constr. Manag. Econ. 2016, 34, 61-75. [CrossRef]

30. Adamczyk, J.; Dylewski, R. The impact of thermal insulation investments on sustainability in the construction sector. Renew. Sustain. Energy Rev. 2017, 80, 421-429. [CrossRef]

31. Zhao, Z.-Y.; Zhao, X.-J.; Davidson, K.; Zuo, J. A corporate social responsibility indicator system for construction enterprises. J. Clean. Prod. 2012, 29, 277-289. [CrossRef] 
32. Zolfani, S.H.; Pourhossein, M.; Yazdani, M.; Zavadskas, E.K. Evaluating construction projects of hotels based on environmental sustainability with MCDM framework. Alex. Eng. J. 2018, 57, 357-365. [CrossRef]

33. Ghisellini, P.; Ji, X.; Liu, G.; Ulgiati, S. Evaluating the transition towards cleaner production in the construction and demolition sector of China: A review. J. Clean. Prod. 2018, 195, 418-434. [CrossRef]

34. Bonenberg, W.; Kaplinski, O. The Architect and the Paradigms of Sustainable Development: A Review of Dilemmas. Sustainability 2018, 10, 100. [CrossRef]

35. Pan, M.; Linner, T.; Pan, W.; Cheng, H.; Bock, T. A framework of indicators for assessing construction automation and robotics in the sustainability context. J. Clean. Prod. 2018, 182, 82-95. [CrossRef]

36. Laitinen, H.; Ruohomäki, I. The effects of feedback and goal setting on safety performance at two construction sites. Saf. Sci. 1996, 24, 61-73. [CrossRef]

37. Hegazy, T.; Abdel-Monem, M. Email-based system for documenting construction as-built details. Autom. Constr. 2012, 24, 130-137. [CrossRef]

38. Choudhry, R.M. Behavior-based safety on construction sites: A case study. Accid. Anal. Prev. 2014, 70, 14-23. [CrossRef] [PubMed]

39. Hienonen, M.; Räinä, I.; Tackett, E.; Kauppinen, T. The Importance of Building Physics in Improving the Quality Control of Buildings-The Role of Public Authority. Energy Procedia 2017, 132, 99-104. [CrossRef]

40. Han, S.; Saba, F.; Lee, S.; Mohamed, Y.; Peña-Mora, F. Toward an understanding of the impact of production pressure on safety performance in construction operations. Accid. Anal. Prev. 2014, 68, 106-116. [CrossRef]

41. Hardison, D.; Behm, M.; Hallowell, M.R.; Fonooni, H. Identifying construction supervisor competencies for effective site safety. Saf. Sci. 2014, 65, 45-53. [CrossRef]

42. Altinay, L.; Brookes, M.; Madanoglu, M.; Aktas, G. Franchisees' trust in and satisfaction with franchise partnerships. J. Bus. Res. 2014, 67, 722-728. [CrossRef]

43. Altinay, L.; Brookes, M. Factors influencing relationship development in franchise partnerships. J. Serv. Mark. 2012, 26, 278-292. [CrossRef]

44. Brookes, M.; Altinay, L. Franchise partner selection: Perspectives of franchisors and franchisees. J. Serv. Mark. 2011, 25, 336-348. [CrossRef]

45. Kines, P.; Andersen, L.P.; Spangenberg, S.; Mikkelsen, K.L.; Dyreborg, J.; Zohar, D. Improving construction site safety through leader-based verbal safety communication. J. Saf. Res. 2010, 41, 399-406. [CrossRef] [PubMed]

46. Sanz, R. A CORBA-based architecture for strategic process control. Annu. Rev. Control 2003, 27, 15-22. [CrossRef]

47. Krakhmal'Ny, T.; Evtushenko, S.; Krakhmal'Naya, M.; Evtushenko, S. New System of Monitoring of a Condition of Cracks of Small Reinforced Concrete Bridge Constructions. Procedia Eng. 2016, 150, 2369-2374. [CrossRef]

48. Wang, T.; Gao, S.; Li, X.; Ning, X. A meta-network-based risk evaluation and control method for industrialized building construction projects. J. Clean. Prod. 2018, 205, 552-564. [CrossRef]

49. Montmain, J.; Gentil, S. Dynamic causal model diagnostic reasoning for online technical process supervision. Automatica 2000, 36, 1137-1152. [CrossRef]

50. Misiurek, K.; Misiurek, B. Methodology of improving occupational safety in the construction industry on the basis of the TWI program. Saf. Sci. 2017, 92, 225-231. [CrossRef]

51. Central Statistical Bureau of Latvia. Available online: https://www.csb.gov.lv (accessed on 21 July 2019).

52. Construction Merchants Register. Available online: https://bis.gov.lv/bisp/lv/construction_companies?utf8 =\%E2\%9C \%93\&direction=\&sort=\&search $\% 5 B$ name $\% 5 \mathrm{D}=\&$ search $\% 5$ Bregister_number $\% 5 \mathrm{D}=\&$ search $\%$ 5Bcode $\% 5 \mathrm{D}=\&$ search $\% 5 \mathrm{Bstatuses} \% 5 \mathrm{D} \% 5 \mathrm{~B} \% 5 \mathrm{D}=\mathrm{A} \&$ search $\% 5 \mathrm{Bqualification}$ _lass $\% 5 \mathrm{D}=\&$ search $\% 5 \mathrm{Bsearc}$ h_type $\% 5 \mathrm{D}=$ simple\&commit=Mekl\%C4\%93t (accessed on 22 July 2019).

53. Construction Inspectors Register. Available online: https://bis.gov.lv/bisp/lv/building_inspectors?utf8=\%E 2\%9C $\% 93 \&$ search $\% 5$ Bdirection $\% 5 \mathrm{D}=\&$ search $\% 5 \mathrm{Bsort} \% 5 \mathrm{D}=\&$ search $\% 5 \mathrm{Bname} \% 5 \mathrm{D}=$ \&search $\% 5 \mathrm{Blast}$.n ame $\% 5 \mathrm{D}=\&$ search $\% 5$ Bregister_number $\% 5 \mathrm{D}=\&$ search $\% 5$ Bstatus $\% 5 \mathrm{D} \% 5 \mathrm{~B} \% 5 \mathrm{D}=$ active\&search $\% 5 \mathrm{Bsearch}$ _type $\% 5 \mathrm{D}=$ simple\&commit=Mekl\%C4\%93t (accessed on 30 May 2019).

54. Construction Law. Available online: https:/likumi.lv/ta/id/258572-buvniecibas-likums (accessed on 12 April 2019). 
55. Bell, M.L.; Teixeira-Pinto, A.; McKenzie, J.E.; Olivier, J. A myriad of methods: Calculated sample size for two proportions was dependent on the choice of sample size formula and software. J. Clin. Epidemiol. 2015, 67, 601-605. [CrossRef] [PubMed]

56. Mjakuškina, S.; Kavosa, M.; Uzulēns, J.; Lapina, I. The analysis of supervision process in the field of construction: Case in Latvia. In Proceedings of the 21st QMOD-ICQSS Conference "The Quality Movement-Where Are We Going? Past, Present, and Future": Proceedings, Cardiff, UK, 22-24 August 2018.

(C) 2019 by the authors. Licensee MDPI, Basel, Switzerland. This article is an open access article distributed under the terms and conditions of the Creative Commons Attribution (CC BY) license (http://creativecommons.org/licenses/by/4.0/). 